\title{
Civic and nationalism education for young Indonesian generation in the globalization era
}

\author{
Mukhamad Murdiono ${ }^{1}$, Wuri Wuryandani ${ }^{2}$ \\ ${ }^{1}$ Pancasila and Civic Education Study Program, Universitas Negeri Yogyakarta, Yogyakarta, Indonesia \\ ${ }^{2}$ Primary School Teacher Education Study Program, Universitas Negeri Yogyakarta, Yogyakarta, Indonesia
}

\section{ABSTRACT}

This study aims to describe nationalism education for young Indonesian generation in the globalization era. This is descriptive qualitative research conducted in several Senior High Schools. The data were collected through interviews, observation, and documentation. The research subjects were Civic Education teachers in Yogyakarta Province and students who attended the Civic Education classes. The collected data were then analyzed with the inductive analysis technique. The results revealed two nationalism education models for the young generation in the globalization era: promoting nationalism through Civic Education and extracurricular activities. Teachers promote nationalism by developing learning methods, learning materials, learning media, and student worksheets incorporating nationalism values. Meanwhile, extracurricular activities in schools were carried out through activities that promote

Article History:

$\begin{array}{ll}\text { Submitted } & : 16-03-2021 \\ \text { Revision } & : 06-04-2021 \\ \text { Accepted } & : 30-04-2021\end{array}$

Keywords:

nationalism, the young

generation, globalization


nationalism.

\section{Cite in APA ${ }^{7 \text { th }}$ :}

Murdiono, M., \& Wuryandani, W. (2021). Civic and nationalism education for young Indonesian generation in the globalization era. Jurnal Civics: Media Kajian Kewarganegaraan, 18(1), $158-171$. https://doi.org/10.21831/jc.v18i1.39452

\section{Introduction}

Globalization occurring in almost all countries in the world is marked by technological advances. Technological advances, especially communication and information technology, create the increasingly borderless world. Someone in a particular country can quickly notice events that occur in another country. Information travels fast to various parts of the world with the help of Internet technology. The use of Internet technology makes it easier for people to access information regardless of time and places. The internet plays a crucial role in the information and idea exchanges between government and citizens (Kim, Kavanaugh, \& Hult, 2011). A world without borders in the globalization era do not only creates easy information access for a country, but it also presents challenges that must be faced by every country.

The fast paced information exchanges impact the lives of people around the world. A country's ideologies, lifestyles, and beliefs may affect the established habits and life patterns of other countries. Core values such as the nation's ideology as the long established guidance for citizens to conduct their lives are slowly weakened. The weakening of ideological influences on people's lives can be seen from the younger generation's behaviours. They tend to adopt global trends, such as a hedonistic and consumptive lifestyle. Excessively imitating the global trends can weaken the core values of our country. 
The growing globalization affects every aspect of people's lives, including beliefs, norms, values, behaviour, economy, and trade (Banks, 2008). Global trends can also diminish the nationalistic values of the younger generation in Indonesia. This issue can be encountered by strengthening the nationalistic values through education, particularly Civic Education.

Civic Education has a strategic role in strengthening the nationalistic values. Civic Education is expected to help students develop identity and attachment to the global community and human relationships around the world. Hence, it has a vital role in developing young people to be smart and good citizens. Good citizenship is reflected in at least three main aspects of quality Civic Education, i.e. citizenship knowledge, citizenship skills, and citizenship characteristics (Titus, 1999). Citizenship knowledge, among other things, is related to what citizens should know. Citizenship skills are reflected in intellectual and participatory skills. The characteristics of citizenship are the main public and private characteristics that every citizen should possess for the maintenance and development of constitutional democracy.

Civic Education to build nationalism among students as young Indonesian citizens is indispensable. The younger generation will face a new world order. They may interact with individuals from a wide variety of ethnicities, genders, languages, races and socioeconomic backgrounds. They will experience some serious challenges such as health, injustice, environmental degradation, population explosion, transnational migration, ethnic nationalism, and the decline of the nation-state. All children, regardless of the place of birth, have the right to education. However, children who successfully complete education in the 21st century must be well prepared with the attitudes, knowledge and skills they need to become competent and responsible citizens.

Students with strong awareness tend to be reliable, more careful, conscientious, responsible, organized, achievement-oriented, and continuously ready. Students with high hospitality are generally considered kind, flexible, cooperative, caring, polite, confident, and tolerant (Bourke et al., 2012). Students' experiences take parts in forming their personalities as citizens of the world. Research proves that Civic Education is proven to be effective in building political competence as well as democratic and responsible young citizens (Gainous \& Martens, 2012).

Citizenship Education must be continuously developed to equip young citizens with a sufficient global understanding. A re-conception of Civic Education is necessary to effectively educate students to be functioning citizens (Banks, 2008). For a successful re-conception, the underlying knowledge construction must shift from mainstream academic knowledge to transformative academic knowledge. Mainstream knowledge strengthens traditional knowledge and established social sciences as well as behaviours and knowledge institutionalized in popular culture, both in schools and colleges.

One of the essential goals of transformative knowledge is to enhance human capabilities as global citizens. Transformative Civic Education recognizes and validates students' cultural identities. It is rooted in transformative academic knowledge and enables students to acquire the information, skills and values necessary to fight inequality in society, nations, and the world. In addition, students are expected to develop values and global perspectives, to take action, and to create justice in a multicultural democratic community. This encourages critical thinking skills, known as critical civic education (Banks, 2008).

From the description of the problems that have been put forward, researchers are interested in conducting research on nationalism education for Indonesia's young generation carried out in schools. Developing a conceptual-philosophical framework on nationalism 
education is an urgent and strategic step as a part of the development of a basis for making nationalism education policies for the younger generation in the globalization era more contextual. Research related to nationalism education in Indonesian context is rarely conducted. The current research is expected to enrich both theoretically and practically in developing nationalism education for the younger generation in the globalization era.

\section{Indonesian Nationalism}

The importance of strengthening the nationalism of Indonesian citizens was once emphasized by former President Soekarno before Indonesia's independence. When delivering a speech about the basis of the state before the Indonesian Independence Preparatory Investigation Agency's (BPUPKI) congress on June 1, 1945, Soekarno stated that the recommended nationality was not chauvinism, but one that led to the kinship of the nations of the world (internationalism). Furthermore, in his speech, Soekarno said that internationalism could not flourish unless it were rooted in nationalism. Nationalism cannot thrive if it does not live in the internationalism perspective (Latif, 2011). Soekarno's idea of internationalism later became the embryo of the importance of Indonesia's involvement in international communities. Fostering the spirit of nationalism after recently claiming independence was indeed very important. However, the Indonesian people also realized that they were part of the world. Therefore, the Indonesian nation needs to be involved in international communities.

The globalization process that is increasingly sweeping the world requires every nation to have an internationalist perspective. This insight is needed in order to participate in implementing the world order that guarantees freedom, eternal peace and justice. A paradigm shift in international relations from the principle of "zero-sum-game" to "win-win-solution" is necessary. This method can be pursued by expanding democratic practices across the boundaries of the nation-state, through strengthening deliberation, restructuring multilateral institutions, and citizen participation in universal humanitarian issues (Latif, 2011). Therefore, it is crucial for citizens to develop a global understanding. Understanding of various global problems is beneficial for citizens to carry out their role to participate in humanitarian issues across the boundaries of the nation-state.

Internationalism proposed by Soekarno is not in the sense of cosmopolitanism which does not recognize nationalism; rather, internationalism in this context has a close relationship with nationalism (Fatwa, 2010). Soekarno's idea of internationalism then appeared in the preamble to the 1945 Constitution as one of the goals of the establishment of the Republic of Indonesia. In the fourth paragraph of the opening, it is stated that the purpose of the establishment of the Republic of Indonesia is to protect the entire Indonesian nation and all Indonesian blood, promote public welfare, educate the nation's life, and participate in implementing world order based on independence, eternal peace and social justice. The first three goals are the internal goals and the last one as the external goal. Therefore, an understanding of global insights for citizens is fundamental.

Nation's education is then juridically-constitutionally elaborated through more detailed statutory regulations in Law Number 20 of 2003 concerning the National Education System. The importance of understanding global understanding is explained in article 36 paragraph 3 point (i) which states that the curriculum is arranged according to the level of education within the framework of the Republic of Indonesia by taking into account the dynamics of global development. This provision clearly proves that in addition to strengthening and strengthening nationalism, education developed in Indonesia must also contain the dynamics of global development. Therefore, there is no reason to rule out the importance of understanding global 
understanding in the education system in Indonesia. Civic Education, as part of the national education curriculum, has a strategic role in building nationalism as well as the global understanding of young citizens.

To build a global understanding of young citizens, Civic Education emphasizes developing students' attitude and willingness to interact with fellow humans based on the principles of protecting human dignity as the noblest creatures. Two principles are underlying the citizen's moral principles, i.e. sympathy and respect. Sympathy reflects values and attitudes of paying attention to others, especially those in need. Respect is defined as a person's ability to protect himself from actions that can harm or interfere with the rights of others (Zamroni, 2007). Thus, the development of Civic Education in addition to emphasizing the aspects of knowledge, values, and attitudes, must also foster respect and empathy that is global in nature, transcending national and state boundaries.

Citizens living in a particular country do not live alone. There are other people with different ethnic backgrounds, nations, races, religions, beliefs and languages. Humans need to have an understanding of the differences and the ability to respect each other's differences. Therefore, it is vital for every citizen to develop a global understanding in order to be able to understand the importance of multiculturalism.

The symbiotic relationship between internationalism and nationalism took on a new dimension during the Japanese occupation of World War II (1942-1945). The Japanese victory over the Dutch created a distinct impression on the Indonesian people. The Indonesian people had the confidence that if they had the same strength, they would be able to do what Japan had done to the Dutch. The transition of power from Japan to the Netherlands did not change its character as a colonial nation. The Indonesian nation, as a colonized nation continues to suffer. The Japanese occupation turned out to have an impact on the strengthening of the nationalism spirit (Latif, 2011). The struggle of the Indonesian nation against Japanese colonialism reached its momentum when Japan suffered defeats in the Pacific War. The defeat of Japan from the Allied Forces provided an opportunity for the Indonesian people to determine their own international choices and orientation. Indonesian people no longer depend on Japan for independence.

Nationalism in the modern era is often juxtaposed and even contradicted by the term cosmopolitanism. Nationalism and cosmopolitanism are two things that are not separate but continuous (Kendall et al., 2008). Cosmopolitanism is not synonymous with moral freedom; instead it is only an institutional vehicle for actualization. Cosmopolitanism has not always opposed nationalism in a way that is contrary to universalism particularism (Cheah, 2006).

Cosmopolitanism is a willingness to engage with others. Amid cultural diversity, cosmopolitanism seeks to recognize human goodness. Cosmopolitanism emphasizes that in the era of globalization, humans are expected to live, survive or develop without being local, direct and exclusive (Ossewaarde, 2007). In the 21st century globalization, it is necessary to combine the spirit of nationalism with cosmopolitanism. In the global era, national citizenship should not be rejected; citizenship must contain national and multinational dimensions (Cogan \& Derricott, 1998).

Internationalism and humanity proclaimed by Soekarno were very different from cosmopolitanism. In his view, cosmopolitanism does not recognize nationality. Internationalism is more appropriate to serve as a philosophical foundation for the establishment of the Indonesian nation than cosmopolitanism. This internationalism was then used as the second principle of Pancasila in Soekarno's speech. The close relationship between the conceptions of nationalism and internationalism has consequences for a just and civilized humanitarian orientation, and these 
are dual principles. The first of the dual principles is outward orientation, participating in fighting for world peace and justice. Meanwhile, the inward orientation honours human rights as individuals and groups (Latif, 2011). In the globalization, nationalism, internationalism and cosmopolitanism are concepts that need to be contextualized. Therefore, the global change process can be well defined.

\section{Nationalism in the Globalization Era}

The terms nation and nationality are often mentioned when talking about nationalism, even though these terms are not easy to define, let alone analyze. A nation is an imagined political community (Anderson, 2006). The members of a nation will never know most of the other members, but in their minds lives the image of their fellowship. Furthermore, Anderson gave an example that a village in Java could be connected with other villages outside Java, even though people living in Java had never seen and knew people outside their territory. A nation is more than just an imagined community; a homeland must also be imagined (Fukuyama \& Billig, 1996).

The concept of natio comes from Latin, which is entirely different from the meaning of 'nation'. The ancient definition of natio is used as broadly as tribes (Nairn \& James, 2005). A nation in the sense of the term is something new in history. A nation is a soul, a spiritual principle. Two things are one, i.e. the past and the present (Bhabha, 2013). Nationalism and the nation-state are generally regarded as a modern phenomenon associated with the rise of European and global capitalism. The nation emerged as a consequence of a combination of the intensification of production, the emergence of capitalism and the ideals of the French Revolution (King, 2002).

Nationalism is defined as an ideology which argues that humans carry out proper political organization in an independent, sovereign nation-state based on cultural uniqueness (Dingley, 2008). Nationalism is an ideology by the nation, but modern nationalism always attributes itself to nations as its political platform. This ideology demands loyalty from its citizens to the nation-state. In fact, only a small number of countries in the world have a single nationality. The majority of nation-states are multinational states with a diversity of customs, traditions and aspirations of diverse ethnic groups. Under these conditions, the loyalty of citizens is often divided. On the one hand, a citizen is loyal to the state as his political umbrella, but on the other hand, he has loyalty to his tribe as cultural protection and cultural affiliation (Musa, 2011). The specificity of nationalism distinguishes nationality from other types of identity, stemming from the fact that nationalism locates the source of individual identity which is seen as the bearer of sovereignty. In subsequent developments, nationalism was known in various forms. There are various nationalism types, such as liberation nationalism, cultural nationalism, ethnic nationalism, civic nationalism and religious nationalism.

Liberation nationalism is a form of nationalism which states that all countries, including liberal ones, must promote and instil a sense of common nationality between each citizen (Tan, 2004). Nationalism, in this form, considers the state of being a homogeneous nation-state. Cultural nationalism is nationalism that requires group members to share the history and culture to be passed on to the next generation. In cultural nationalism, the position of the state is very meaningful, and all national culture is the primary goal. Nationalism is identified by the claim that national culture is an essential component of people's identity and that the world must be regulated institutionally (Gans, 2003).

The conception of nationalism is closely linked with other concepts such as internationalism and cosmopolitanism. Understanding these various concepts is an integral part of analyzing the ongoing globalization process in the world. The rapid flow of globalization touches almost all 
aspects of human life; this may impact on the re-conception of the nationalism concept. There are concerns that the values of nationalism will fade due to the globalization waves occurring in various parts of the world. Therefore, a new formulation is needed regarding the form of nationalism in the global era.

Nationalism in the globalization era will find a new context that is different from the nationalism of the previous era. The state is never obsolete but is changing to its new form. The nation-states in the world will remain strong and stable if their citizens and leaders are responsive to the globalization process. The nation-state will continue to act as the primary locus for the identity of its citizens, as long as no other institution can adequately replace it as the fundamental unit in the global changes. Nation-state still has a central role in dealing with international human rights issues (Latif, 2011). The nationalism that the Indonesian nation wants to develop is nationalism in a broad perspective with internationalism dimension.

The rapid globalization process all over the world requires every nation to have an internationalist perspective. This insight is essential to achieve the external goal, i.e. participating in implementing the world order based on eternal peace and social justice. The internationalism that was put forward by Soekarno before independence was internationalism with a kinship dimension. This kind of does not refer to chauvinism. As a consequence, Indonesia must be actively involved in international communities.

Globalization is an important term studied by experts from various countries. In France, globalization is called mondialisation. Spain and Latin America call it globalizacion. Meanwhile, Germany uses the term globalisierung (Giddens, 1999). Unlike other concepts in the field of economics and politics that have long been recognized by the world community, globalization is a new term in English. Academic discussions on globalization began from the 1980s to mid-1990s. Globalization is the most crucial keyword of intellectual movements in several countries in the world. The term globalization appears in academic discussions in parallel with other terms such as cosmopolitanism, connectivity, networks, hybridization, interdependence, space-time compression, and other similar terms (Ampuja, 2012).

Globalization is slowly growing into a strong term and has become a familiar word in almost every country. Globalization can be interpreted as a process of forming an order, rules and systems that apply to nations around the world. Globalization does not recognize regional boundaries, even local and regional rules this might reduce the values, ideas, thoughts of the international community (Sumner, 2008).

Globalization does not only mean interdependence, and it does not only examines global institutions. Economic globalization has strengthened the interdependence of several developing countries (Sassen, 2007). Globalization opens the broadest possible space to conduct research on various unresolved international problems. The globalization process has further strengthened the market at a global level. The globalization process is a process that transcends time and space boundaries. Globalization affects people's daily lives as well as international scale events (Giddens, 1999). The development of the latest science and technology has allowed the globalization process to strengthen the market further. The implications of the globalization process will be politically, economically, and socially broader. In the context of nationalism and the nation-state, the globalization process driven by international market forces has been responded by the strengthening of the local communities' independence. Both globalization and regional autonomy are mutually attractive, and the nation-state with its nationalism is perceived as increasingly irrelevant (obsolete) at present (Seda, 2011). 
Other definitions of globalization are values and interdependence. The Western world has a significant role in the process of globalization, because what happens in the Western world will grow and develop throughout the world (Rasmussen, 2002). The victory of the West in the Cold War has made it possible to define the world on its developed terms and gives reasons to believe that the world will, in time become like the West. Globalization becomes a conceptual guide for the analysis of the processes, structures and politics of the post-Cold War. Globalization refers to a process that not only provides new insight, but can also explain and define the political, economic, and social world. Globalization that has been transformed into real action is known as globalism. Globalism is a political act that is justified in globalization.

Another perspective states that globalization is a new form of imperialism, especially in the economic field. The global expansion of capital over the past 100 years has had mixed effects on economies, countries, and class relations on a world scale. Imperialism and global capitalism are the inevitable consequences of the 20th-century monopoly capitalism. Globalization is a new form of imperialism or an element inherent in imperialism (Berberoglu, 2009); (Sakellaropoulos, 2009).

Some of the characteristics of the new imperialism include War that never ends, the existence of geographical boundaries, and has a specific purpose. Imperialism was only created after World War II. The new imperialism has five essential elements which include the formation of a monopoly, the creation of financial capital, an increase in the export of capital assets, the formation of multinational companies, and the division of the world between powerful countries (Sakellaropoulos, 2009). Neoliberal globalization has penetrated almost the whole world. It is not an exaggeration if in the subsequent developments many have fought against globalization (antiglobalization).

The labour movement, anti-imperialist movements, civil rights fighters, women, students, the environment, anti-war, and peace movements all contributed to the development of the antiglobalization movements that arose in the early 21st and late $20^{\text {th }}$ centuries (Berberoglu, 2009). Resistance or criticism of globalization has more to do with economic globalization and its impacts. Economic globalization is seen as a new form of global capitalism. In capitalism will emerge monopoly, oligarchy, and exploitation by strong countries against weak (poor) countries.

Globalization is currently a matter of debate among experts. The debate regarding globalization lies in two crucial areas. First, the narrower area is more on economic issues. Meanwhile, in the second area, globalization is interpreted more broadly. Globalization is more debated on the issue of ideas as a basis for the development of a social theory (Kiely, 2005).

The continuous globalization process all over the world is at least marked by several things. There are at least four signs of globalization that can be observed from the ongoing process. First, globalization cannot be separated from advances and innovations in the fields of technology, communication and information flow that cross national borders. Second, globalization will always be related to capital accumulation. Third, globalization is related to the increasing intensity of human migration, the transfer of cultures, and values and ideas across national borders. Fourth, globalization is marked by increasing interconnectedness and dependence, both between nations and between communities in the world (Ilahi, 2012). The signs of the globalization process are evident in our lives today, both on a local, regional and international scale.

There are three possible options in dealing with globalization. The first option is by being optimistic. This choice is mainly taken by business people and governments of developed countries. This choice often raises the problem of not paying attention to the negative impacts of globalization. Second, the skeptical choice. This choice is taken by those who have understood 
globalization as economic independence, political ideology, science, and technology that do not take human safety into account. For the groups that chose this option, globalization is nothing but the colonialization of new ideological politics. Third, the compromise-critical choice. This choice means that even though they are involved in economic globalization and political ideology, they still have hope for the development of science due to the influence of globalization (Ilahi, 2012). The choices in facing globalization cannot be forced, but instead, become a requirement faced by every human being in the global era. Every citizen will choose options in the face of globalization that can provide benefits, both personally and socially.

Globalization affects almost all aspects of human life. Initially, globalization occurred in the centres of the superpowers. However, in its development, it hit almost all countries around the world. The widespread globalization affects the development of nation-states in the world. The rapid globalization has resulted in the interconnectedness of various essential elements in the global, regional and local scope. The impact of globalization is ambiguous or known as the global paradox (Latif, 2011). Global paradox means that the globalization process that occurs in various parts of the world provides opportunities and obstacles. The impact of globalization can be positive and can also be damaging. It depends on how a country interprets the ongoing globalization process.

For Indonesia, the modern globalization has brought national politics to the third wave of democratization through the reformation movement in the late 1990s. This democratization wave is getting more potent as a result of the penetration of global powers. After the Cold War ended, this penetration came from the strength of the market and religious fundamentalism (Latif, 2011). The open market opens up opportunities for countries to engage in global competition. On the other hand, the democratization fosters new religious sects, at which during the New Order government were silenced. Religion-based mass organizations have flourished, from mass organizations that are very tolerant of other groups with different views to those that are more radical.

The growing democratization flow as a result of globalization has encouraged the emergence of regional autonomy. Regional expansion is an integral part of the growing demands for regional autonomy. Various laws and regulations governing regional autonomy are designed and issued. In fact, the number of provinces and districts or cities in Indonesia is increasing. The expansion of the area gives new hopes for community members to live more prosperously. However, not all demands for regional autonomy is fruitful to increase people's prosperity. Various problems related to regional autonomy arise, ranging from the lack of human resources in managing the government to the depletion of natural resources. There are local governments that ultimately erode their natural resources just to meet the local revenue. This results in environmental damage which greatly impacts people's lives.

From the theoretical discussion, globalization can be interpreted as a global process. The term globalization appears parallel to other terms such as cosmopolitanism, connectivity, networks, hybridization, interdependence, and other terms often appeared in academic discussions. Globalization is a process of forming orders, rules and systems that apply to nations throughout the world. Globalization crosses the territorial boundaries of a country, making a country's borders increasingly blurred. Globalization occurs in almost all areas of human life, such as politics, economy, social, culture, and other aspects. In the economic field, globalization is more visible with the expansion of markets and the influence of global capitalism.

Globalization affects all aspects of human life, bringing positive and negative impacts. In the Indonesian context, globalization as an option must be accepted with a critical-compromise. Globalization as a necessity cannot be denied, but as citizens, we must make choices that can 
provide benefits both personally and socially. Through the compromise-critical, we can choose the positive effects of the globalization process and avoid the negative impacts. Thus, globalization becomes a big challenge as well as an opportunity.

\section{Method}

This is descriptive qualitative research. This study aims to provide a picture of a situation or event, i.e. the nationalism education of young citizens in the globalization era. The research subjects were selected using a purposive sampling technique with specific criteria. The research subjects included high school Civic Education teachers representing each regency/city in the Special Region of Yogyakarta, Indonesia and students who attended Civic Education classes. Teachers and students were considered as people who know a lot and directly practice nationalism education in Civic Education classes.

The data were collected using interviews, observation, and documentation. An interview is a conversation with a specific purpose. The conversation is carried out by two parties, i.e. the interviewers who asked several questions and the interviewees who respond to the questions. In this study, interviews were used to collect data or information related to how teacher's learning models build students' nationalism. Documentation was used to obtain data regarding the description of the object under the study as well as to complement the data from interviews and observations.

In order to obtain data that can be scientifically accounted for, its validity must be checked first. This research employed the triangulation technique, a technique of crossing information obtained from the sources to guarantee the data validity. The triangulation technique used in this research was conducted by double-checking the information from interviews with documentation and observation.

The inductive analysis technique, an analysis that starts from data and leads to general conclusions, was employed. The general conclusion can be in the form of a categorization or a proposition. Data analysis refers to the activity of organizing data into specific arrangements in order to interpret the data. The data were tabulated according to the arrangement of data presentations needed to answer each research problem. The data were interpreted to answer each research problem or the hypothesis as well as the conclusion for the whole problems. The data analysis consists of data reduction, data presentation, and conclusion drawing. These three data analysis steps are a series of analysis activities that follow each other or an interactive cycle process (Miles \& Huberman, 1994).

\section{Result and Discussion}

The results showed that nationalism education developed for the younger generation in schools was carried out through two models, i.e. through Civic Education and extracurricular activities. Civic Education teachers develop learning tools that incorporate nationalism values. Meanwhile, the extracurricular activities also foster students' nationalism to face changes and developments in the globalization era.

The strategy carried out by Civic Education teachers in developing nationalism education for the younger generation is by developing learning tools, such as learning materials, media, methods, and student worksheets, that promote nationalism. Civics Education teachers develop subject matter by incorporating or inserting nationalism values on relevant topics. The media developed by the teacher promotes nationalism in daily life contexts. The teachers also develop learning methods that can foster active participation and promote nationalism in classroom 
learning activities. Furthermore, teachers also develop worksheets and assessments that can measure the students' nationalism level.

Learning materials are developed by incorporating nationalism values into relevant basic competencies. The teachers supplement the existing materials by adding other sources to clarify and strengthen the materials presented. In addition, students are also asked to look for relevant learning materials on the internet or other learning sources, such as magazines, newspapers, newsletters, and the like. Through this method, students can increase their knowledge and strengthen their nationalism in the globalization era.

Media developed by Civic Education teachers to strengthen nationalism are in the forms of pictures and powerpoints about relevant topics. Through pictures, students usually find it easier to understand the content of the material. The pictures presented by the teacher in the classroom as learning media are also used to attract students' attention. The pictures promoting nationalism are expected to influence students.

The learning method used by Civic Education teachers in fostering nationalism is the dialogic-critical learning method. Through this method, students can convey their ideas and thoughts about nationalism for the younger generation in the globalization era. Besides, Civic Education teachers also apply the direct experience method with civic projects. Students develop civic projects by applying nationalism in everyday life. Through the civics project, students learn directly to identify and solve problems related to public policies in their environment. Teachers are required to have creativity in choosing and developing learning methods that can strengthen the younger generation's nationalism in the globalization era.

Teachers also develop worksheets and assessments that incorporate nationalism. Designing students' worksheets that incorporate nationalism depends on teachers' creativity in choosing problems for students to solve. Worksheets are made in the form of descriptions of the diminishing nationalism cases or phenomena among youngsters due to the globalization. Then students analyze and solve these problems. Thus, their critical thinking skills are developed through Civic Education.

The development of students' nationalism through extracurricular activities is conducted outside school hours. Extracurricular activities that can foster nationalism include boy scouts, platoon, and School Security Patrol (PKS). Extracurricular activities organized by schools can develop the students' nationalism in the globalization era. Scouting activities, for example, can foster a self-sacrificing attitude, discipline, tolerance, hard work, and responsibility. Students practice to apply the values contained in each extracurricular activity.

Extracurricular activities are not carried out by the Civic Education teachers, but by other teachers assigned by the school to carry out extracurricular activities. Some extracurricular activities are required by schools, and some are based on specialization for the development of specific talents and skills. Scouting is one of the extracurriculars promoting nationalism for the younger generation. Scouting activities train students to have the abilities necessary in the globalization era.

The research results show that nationalism education for the young generation can be carried out at schools trough Civic Education and extracurricular activities. In Civic education, the teachers develop learning tools such as learning materials, methods, media, and student worksheets. Civic Education has become a vital subject to strengthen the nationalism of the younger generation in the globalization era. Civic Education has an essential role in developing the global outlook for citizens. The young generation living in the 21st century will face a new world 
order. They will come into contact with individuals from various ethnicities, genders, languages, races, and socioeconomic backgrounds (Agbaria, 2011).

The younger generations living in the 21st century may experience some serious challenges such as health, injustice, environmental damage, population explosion, transnational migration, ethnic nationalism, and the decline of the nation-state. In response to those challenges, Civic Education teachers are expected to equip students with experience and a good understanding of globalization effects and the opportunities it offers. In addition, students are trained, and their abilities are developed to have good attitudes by demonstrating such as responsibility, discipline, tolerance, hard work, independence, and democracy. Students with strong awareness tend to be reliable, more careful, conscientious, responsible, organized, achievement-oriented and always ready to become citizens (Bourke et al., 2012). Civic Education is proven to be effective in building the political competence of young citizens who are democratic and responsible (Gainous \& Martens, 2012).

The Civic Education teachers design learning components that incorporate nationalism for the younger generation. An essential part of the learning process is the learning method. Teachers must be able to choose learning methods that strengthen students' nationalism. In addition, the learning method developed must also foster students' critical thinking skills useful in the globalization era. Democratic learning provides the broadest possible opportunities for students to get used to thinking critically and systematically. Civic Education plays a vital role in developing students' critical thinking skills. The Civic Education teachers employ learning methods that are dialogic-critical, direct experience-oriented, collaborative, and cooperative. The aspects fostered in Civic education include knowledge, critical thinking skills, communication skills, cooperation skills, and conflict resolution skills. These aspects require a comprehensive approach that includes inculcation, modelling, facilitation, and skills development (Kirschenbaum, 1995).

Apart from the Civic Education, nationalism education is fostered through extracurricular activities. Schools have an essential role to play in developing extracurricular activities useful for fostering students' personality. School as an institution has a very important role in developing character education for students. Schools are institutions that have long been considered as institutions for preparing students to live and develop academically and as moral agents in society. Schools do not only focus on developing students 'academic abilities, but they also need to help students to be accepted by the social environment in which they live (Johansson et al., 2011).

The nationalism education model implemented in schools for students in the era of globalization which has been described illustrates that there are two models that can be applied. The first model, through civic education learning is developed in learning tools by civic education teachers. The second model, through extra-curricular activities organized by schools outside of class hours. Both of these models can be further developed in schools so that students as the younger generation have strong nationalism so that they are able to face challenges in the era of globalization.

This research revealed that two models to foster students' nationalism are implemented in schools. The first model is promoting nationalism through Civic Education classes. Teachers developed learning tools incorporating nationalism for Civic Education classes. The second model is fostering nationalism through extracurricular activities conducted outside the school hours. Further development of the two models might be the answer to encounter the globalization challenges by fostering the young generation's nationalism. 


\section{Conclusion}

The research results suggest that two models are employed to foster young generation's nationalism in schools. The first model is fostering students' nationalism through Civic Education, in which the teachers develop a set of learning tools encompassing learning materials, methods, media, and students' worksheets. The second model is strengthening young generation's nationalism through extracurricular activities. The extracurricular activities are offered by the schools and are under the supervision of teachers and professional trainers. The extracurricular activities are considered able to promote young people's nationalism in the globalization era.

The importance of nationalism education carried out through Civic Education in schools necessitates a curriculum change in the national education system. Nationalism is not merely a small part of Civic Education. It is suggested that specific topics related to nationalism should be added in the curriculum of Civic Education. Curriculum changes are expected to provide students with contextual civic and citizenship competencies and help them prepare more thoroughly to face globalization.

\section{Acknowledge}

This research was funded by the Directorate General of Research and Development Strengthening, Ministry of Research, Technology and Higher Education of the Republic of Indonesia through a national strategic research scheme with research subcontract number: 02 / Penel. / P.STRANAS / UN34.21 / 2017. The research team would like to thank the Civic Education teachers and high school students in the Special Region of Yogyakarta, Indonesia who participated in this research.

\section{References}

Agbaria, A. K. (2011). The social studies education discourse community on globalization: Exploring the agenda of preparing citizens for the global age. Journal of Studies in International Education, 15(1), 57-74. https://doi.org/10.1177/1028315309334645

Ampuja, M. (2012). Globalization theory, media-centrism and neoliberalism: A critique of recent intellectual trends. Critical Sociology, 38(2), 281-301. https://doi.org/10.1177/0896920510398018

Anderson, B. (2006). Imagined communities [electronic resource] : reflections on the origin and spread of nationalism / Benedict Anderson. In ACLS Humanities E-Book. https://doi.org/10.1080/14725843.2011.556797

Banks, J. A. (2008). Diversity, group identity, and citizenship education in a global age. Educational Reseacrh, 37(3), 129-139. https://doi.org/10.3102/0013189X08317501

Berberoglu, B. (2009). The class nature of globalization in the age of imperialism. Critical Sociology, 35(6), 785-800. https://doi.org/10.1177/0896920509343068

Bhabha, H. K. (2013). Nation and narration. In Nation and Narration. https://doi.org/10.4324/9780203823064

Bourke, L., Bamber, P., \& Lyons, M. (2012). Global citizens: Who are they? Education, Citizenship and Social Justice, 7(2), 161-174. https://doi.org/10.1177/1746197912440858

Cheah, P. (2006). Cosmopolitanism. Theory, Culture \& Society, 23(2-3), 486-496. https://doi.org/10.1177/026327640602300290

Cogan, J., \& Derricott, R. (Eds.). (1998). Citizenship for the 21st century: an international perspective on education. Kogan Page. 
Dingley, J. (2008). Nationalism, social theory and Durkheim. In Nationalism, Social Theory and Durkheim. https://doi.org/10.1057/9780230593107

Fatwa, A. M. (2010). Pancasila karya bersama milik bangsa: Bukan hak paten suatu golongan. The Fatwa Center.

Fukuyama, F., \& Billig, M. (1996). Banal nationalism. Foreign Affairs, 75(3), 133-134. https://doi.org/10.2307/20047588

Gainous, J., \& Martens, A. M. (2012). The effectiveness of civic education: Are "good" teachers actually good for "all" students? American Politics Research, 40(2), 232-266. https://doi.org/10.1177/1532673X11419492

Gans, C. (2003). The limits of nationalism. In The Limits of Nationalism. https://doi.org/10.1017/CB09780511490231

Giddens, A. (1999). Runaway world: How globalisation is reshaping our lives. Profile Books.

Ilahi, M. T. (2012). Nasionalisme dalam bingkai pluralitas bangsa: paradigma pembangunan \& kemandirian bangsa. Ar-Ruzz Media.

Johansson, E., Brownlee, J., Cobb-Moore, C., Boulton-Lewis, G., Walker, S., \& Ailwood, J. (2011). Practices for teaching moral values in the early years: A call for a pedagogy of participation. Education, Citizenship and Social Justice, 6(2), 109-124. https://doi.org/10.1177/1746197910397914

Kendall, G., Skrbis, Z., \& Woodward, I. (2008). Cosmopolitanism, the nation-state and imaginative realism. Journal of Sociology. https://doi.org/10.1177/1440783308097129

Kiely, R. (2005). Globalization and poverty, and the poverty of globalization theory. Current Sociology, 53(6), 895-914. https://doi.org/10.1177/0011392105057154

King, L. D. H. (2002). Nations without nationalism: Ethno-political theory and the demise of the nation-state. Journal of Developing Societies. https://doi.org/10.1177/0169796X0201800404

Kirschenbaum, H. (1995). 100 ways to enhance values and morality in schools and youth settings. Allyn \& Bacon.

Latif, Y. (2011). Negara paripurna: historisitas, rasionalitas, dan aktualitas Pancasila. Gramedia Pustaka Utama.

Miles, M., \& Huberman, A. (1994). Miles and Huberman Chapter 2. In Qualitative Data Analysis.

Musa, A. M. (2011). Nasionalisme di persimpangan: pergumulan NU dan paham kebangsaan Indonesia. Erlangga.

Nairn, T., \& James, P. (2005). Global matrix: nationalism, globalism and state-terrorism. Pluto.

Ossewaarde, M. (2007). Cosmopolitanism and the society of strangers. Current Sociology, 55(3), 367-388. https://doi.org/10.1177/0011392107076081

Rasmussen, M. V. (2002). 'A Parallel Globalization of Terror': 9-11, Security and Globalization. Cooperation and Conflict, 37(3), 323-349. https://doi.org/10.1177/0010836702037003676

Sakellaropoulos, S. (2009). The issue of globalization through the theory of imperialism and the periodization of modes of production. Critical Sociology, 35(1), 57-78. https://doi.org/10.1177/0896920508098657 
Sassen, S. (2007). A sociology of globalization. W.W. Norton \& Company, Inc.

Seda, F. S. (2011). Ikatan Budaya, Nasionalisme Indonesia, dan "Ketahanan Budaya" di Tengah Dinamika Globalisasi dengan Desentralisasi: Suatu Kajian Sosiologis. In Nasionalisme dan Ketahanan Budaya di Indonesia: Sebuah Tantangan,. LIPI Press dan Yayasan Pustaka Obor Indonesia.

Sumner, J. (2008). Governance, globalization, and political economy: Perspectives from Canadian adult education. Adult Education Quarterly, 59(1), 22-41. https://doi.org/10.1177/0741713608325170

Tan, K. C. (2004). Justice without borders: Cosmopolitanism, nationalism, and patriotism. In Justice without Borders: Cosmopolitanism, Nationalism, and Patriotism. https://doi.org/10.1017/CBO9780511490385

Titus, C. (1999). Civic Education untuk pemahaman global. In M. S. Branson (Ed.), \& M. N. K. Syafruddin, M. Yasir Alimi (Trans.), Belajar Civic Education dari Amerika.

Zamroni. (2007). Pendidikan dan demokrasi dalam transisi: prakondisi menuju era globalisasi. PSAP Muhammadiyah. 